\title{
PROPERTY, POSSESSION, AND PRESCRIPTION: THE RULE OF LAW IN THE HESSIAN AND RHINE-MAIN REGION OF GERMANY, 1648-1776
}

COLIN F. WILDER*

\author{
Advisor: Constantin Fasolt \\ University: University of Chicago \\ Date of Graduation: August 2010 \\ Language: English
}

In early modern German society, lawsuits over property rights occasioned the development of natural law jurisprudence. This constituted a common law mind in Germany, with affinities to the natural rights tradition associated with English liberals such as John Locke. Taking the example of the Hessian Rhine-Main region in the period 1648-1776, this dissertation examines lawsuits, casebooks, and theoretical treatises, revealing the steady construction of economic liberalism, rule of law, and measured civil rights long before the French Revolution visited the region in 1806. After 1648, post-war reconstruction and new establishment of courts and universities were the enabling conditions for a significant growth in both rights-claims and a jurisprudence that sought to sort those claims out. This jurisprudence was characterized by growing universality and objectivity, meaning growth of common rules, formal legal equality, and more precise interpretations. Post-war property rights theory was heir to Roman law, canon law, scholasticism, Protestant natural law, and English natural rights theories, yet sought to integrate these influences with a dawning sense of the distinctiveness of German customs. What changed over time were less ideas and rules than the applications or deployments of ideas and rules; for instance, in lawsuits or in teaching and publishing. One major area was real estate, meaning the control of space and of rights attached to it. Real estate law grew more objective in three areas especially: collective property organization; owners' rights; and the ability of mere tenants of land, such as feudal leaseholders or widows on family land, to convert their holding into alienable ownership. By the late eighteenth century, property, use-rights, easements, jurisdictions, and, indeed, local government were all treated as assets with various appurtenant rights. The expansion of such property rights rules-for instance, in the area of law merchant-brought with it more freedom, power, and responsibility to property holders. This feedback loop of practice and theory formed the institutional framework for the growth of later capitalist society.

\footnotetext{
*Brown University, Political Science Department
} 